\title{
Dictynna
}

Dictynna

Revue de poétique latine

4 | 2007

Varia

\section{Claudia Quinta (Pro Caelio 34) and an altar to Magna Mater}

Eleanor Winsor Leach

\section{(2) OpenEdition \\ Journals}

\section{Electronic version}

URL: http://journals.openedition.org/dictynna/157

DOI: $10.4000 /$ dictynna.157

ISSN: 1765-3142

\section{Publisher}

Université de Lille

\section{Electronic reference}

Eleanor Winsor Leach, « Claudia Quinta (Pro Caelio 34) and an altar to Magna Mater », Dictynna [Online], 4 | 2007, Online since 29 November 2010, connection on 21 December 2020. URL : http:// journals.openedition.org/dictynna/157 ; DOI : https://doi.org/10.4000/dictynna.157

This text was automatically generated on 21 December 2020.

\section{(c) (i) () $९$}

Les contenus des la revue Dictynna sont mis à disposition selon les termes de la Licence Creative Commons Attribution - Pas d'Utilisation Commerciale - Pas de Modification 4.0 International. 


\title{
Claudia Quinta (Pro Caelio 34) and an altar to Magna Mater
}

\author{
Eleanor Winsor Leach
}

1 The relocation during the 1990's - whether permanent or merely temporary - of many items of sculpture from the Capitoline collections in the Museum of the Power Plant Montemartini has given a new visibility to several items as interesting for their cultural significance as for their artistry. One of these is a marble relief altar discovered on the bank of the Tiber below the Aventine under the papacy of Clement XI at some time between 1700 and 1721. The face of the altar bears a dedicatory inscription and a pictorial allusion to the arrival by ship at Rome of the goddess Cybele. ${ }^{1}$ (Figure 2). On the altar's back face are two flutes, while the right side has a pedum and cymbal and the left a Phrygian cap, all unmistakably referring to Cybele's Phrygian origins and her association with the myth of Attis. ${ }^{2}$

2 The central image is a small ship with a curved stern plume and a volute prow. The goddess enthroned at the center should probably be imagined within the aedicula shell behind her. She is fully enveloped in a veil, chiton and himation with one hand resting on her knee and another raised with a tympanum. ${ }^{3}$ Around the capstan on the bow is wrapped a short pull whose other end falls lightly from the hand of a woman positioned obliquely to the front of the boat on a projecting square platform. She also has her head veiled and she wears a chiton wrapped closely over her breast and fastened in the manner of the goddess, but her mantle is loosely draped over the free arm. The dedicatory inscription names the goddess and, surprisingly, gives a name to the ship (CIL VI 492) ${ }^{4}$

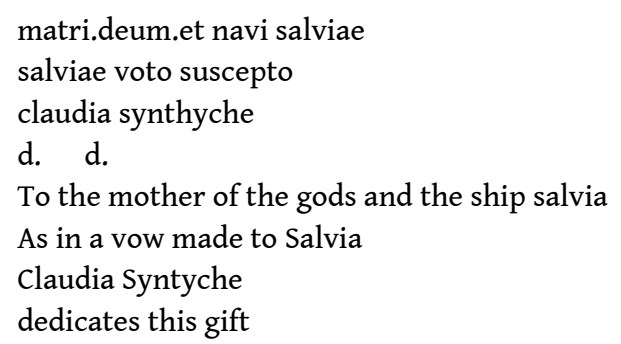


historical and poetic, certan idiosyncrasies of the iconography and the inscription historical and poetic, certain idiosyncrasies of the iconography and the inscription added to the otherwise unknown identity of the dedicator prompt questions concerning the altar's particular association with time and place.

Sources leave no doubt as to the identity of the figure who tows the boat, no other than Claudia Quinta a celebrated woman of the Republican third century traditionally associated with the reception of the goddess. Among the many contexts in which she receives mention, the first extant instances are in two of Cicero's orations. Readers familiar with his Pro Caelio may recall how the orator brings her on stage in a cameo appearance to bolster his case against the controversial Clodia Metelli as one of the accusers of his client M. Caelius Rufus. In a sensational prosopopoeia, he assumes the mask of Appius Claudius Censor, a figure summoned, as it were, ab inferis, and with this voice invokes the praiseworthy memory of the third century ancestress, Claudia Quinta, in the name of familial honor, as an index of reproach to her descendent (Pro Caelio 14.34): ${ }^{5}$

«Nonne te, si nostrae imagines viriles non commovebant, ne progenies quidem mea, Q. illa Claudia, aemulam domesticae laudis in gloria muliebri esse admonebat...?» («Is it possible, if the images of our manly ancestors exercised no influence upon you, that not even that offspring of mine, that Quinta Claudia could not exhort you to rivalry in the womanly glory of domestic praise...?»)

5 This evocation has its larger context in Cicero's immediate political warfare with the Clodii, the moment of the oration, April of 56 B.C, being the high point of his active contentions with Clodia's brother P. Clodius Pulcher who had engineered his exile and then continued to attack both his supporters and his property after his return. ${ }^{6} \mathrm{~A}$ month after the pro Caelio, within the religious argument of the de Haruspicum Responsis, he once again flourishes Claudia Quinta's illustrious reputation in the face of present day Claudians. Although the target in this instance is P. Clodius himself, who has allegedly desecrated the Ludi Megalenses by the introduction of a band of slaves, Cicero does not spare an insinuating allusion to Clodia in comparison with her virtuous ancestress. ${ }^{7}$ (de Haruspicum Responsis 13.27):

«femina autem quae matronarum castissima putabatur, Quinta Claudia, cuius priscam illam severitatem [sacrificii] mirifice tua soror existimatur imitata.»

(«...that woman who, however, was considered the most upright of matrons, Quinta Claudia, whose old-fashioned austerity your sister claudia is deemed quite amazingly to have imitated.»)

In both passages the allusion to Claudia Quinta's famous virtue involves her role in receiving the goddess Cybele, Magna Mater, when she arrived at Rome by ship from her seat in Asia Minor during the critical year 204 of the Hannibalic War as a magical presence to secure Roman victory by driving the invader from the land. Roman sources concerning the importation differ on several points: about the location from which the goddess traveled, whether from Pergamon (Varro $L L$ 6.15) or directly from Mt. Ida (Ovid Fasti 4.180-372) or from Pessinus in Galatia (Livy AUC 29. 10-14), ${ }^{8}$ and also the shape in which she arrived, either as a sacred black stone, a meteorite, or else in her own form with mural crown and lions, and even the place of her ceremonial disembarkation, whether at Ostia or at Rome. ${ }^{9}$ As both the Sibylline Books and Delphic Apollo had recommended, the goddess' image and her cult were subsequently installed in a temple of the Palatine, whose dedication in 191 was marked, and thereafter celebrated, by the Megalesian games under the supervision of the curule aedile. 
7 Members of Cicero's audiences need not have been specialists in Claudian family history to understand the orator's references to Claudia's preeminence since any Roman familiar with the Palatine Temple of the goddess should also have known Claudia Quinta from her statue standing within the vestibulum there. This image, according to the later account of Valerius Maximus, had a miraculous history (1.8.11) for it had twice survived untouched on its base amidst flames that consumed the temple. ${ }^{10}$ The first of these occurrences, in 111 B.C., long preceded Cicero's speech. Within the context of the Pro Caelio these references to a publically conspicuous Claudia are interesting since Anne Leen, in a recent article about Cicero's treatment of Clodia Metelli, argues that the orator framed his condemnation in terms of the culturally accepted code of domestic conduct for matrons by situating all her flagrant activities within the interior of the house..$^{11}$ Contrastingly he has called forth Claudia Quinta's virtue from the domestic into the public sphere not simply by her own initiative but rather by civic consensus.

Additionally Ciceronian readers may wonder about the action of Claudia's towing the ship, even asking why Cicero makes no mention of this feature of Claudia Quinta's story which is actually central to its telling in later sources. ${ }^{12}$ Two possible explanations for this discrepancy come to mind: the simpler being that this part of the legend had not yet developed ${ }^{13}$ the more devious that, even if it had developed, Cicero would scarcely have found it advantageous in his defamation to use a version of the story culminating in the miraculous vindication of a Claudian woman's reputation, which is the shape of all post Ciceronian plot-lines from Livy onward. Livy himself implies the element of vindication in a pre-existing account (ut traditur) when he remarks that Claudia's fama, which had previously been dubia was turned into a celebrated example of chastity thanks to her performance of the "religious office», seemingly that of receiving the goddess' image from the hands of a young Scipio Nasica, deemed Rome's optimus vir of the moment, and passing it into those of the other matrons who accompanied her (AUC 29. 14): ${ }^{14}$

«P. Cornelius cum omnibus matronis Ostiam obviam ire deae iussus; isque eam de nave acciperet et in terram elatam traderet ferendam matronis. Postquam navis ad ostium amnis Tiberini accessit, sicut erat iussus, in salum nave evectus ab sacerdotibus deam accepit extulitque in terram. Matronae primores civitatis, inter quas unius Claudiae Quintae insigne est nomen, accepere; cui dubia, ut traditur, antea fama clariorem ad posteros tam religioso ministerio pudicitiam fecit. Eae per manus, succedentes deinde aliae aliis, omni obviam effusa civitate, turibulis ante ianuas positis qua praeferabatur atque accenso ture precantibus ut volens propitiaque urbem Romanam iniret...»

(«P. Cornelius was ordered to proceed with all the matrons to meet the goddess at Ostia in order to receive her from the ship and hand her, transported to dry land, over to the matrons to be carried. After the ship had reached the mouth of the River Tiber, just as he was ordered, being carried on the ship in a sea-swell, he accepted the goddess and carried her to the land. The most distinguished matrons received her, among whom the name of Claudia Quinta stands out, whose reputation, previously rather shaky, as tradition has it, made her modesty celebrated unto future generations by her religious office. Through her hands, with others then succeeding her, and the citizenry streaming all around, and with her preferred form of incense burners placed before doorways and with the incense kindled by persons praying that she would enter the city of Rome in a willing and benevolent spirit...) 
Fantham declares that this narrative reflects the existence of an historical Claudia Quinta, noting with reference to Cicero's de Haruspicum Responsis that she, like young Scipio Nasica may well have been chosen for her office, although perhaps not so much for her upstanding reputation as for the fact that a Claudian cousin, C. Claudius Nero, was censor in $204 . .^{15}$ This simple act of receiving the goddess Ovid in Fasti 4 transforms into a miracle of vindication. His account occurs in the April book of the Fasti, marking the beginning of the Ludi Megalenses festival with an account of Cybele's election, her journey and her installation. By far the most detailed story of Claudia Quinta, it is also the best known, but worth recounting here since Clodia's partisans may wish to see it as an Ovidian riposte to counter Ciceronian defamation. ${ }^{16}$ Not to imagine that Claudian chauvinism has overtaken Ovid, but sophisticated matrons always had the sympathy of the Ars Amatoria poet. Furthermore the language in which he tells Claudia's story seems relevant not only to Cicero's Clodia but Catullus' Clodia/Lesbia as well. In Ovid's story, the chastity of Claudia Quinta had been called into doubt for reasons that read like the template of late Republican defamation of socially conspicuous women (e.g. the clevertongued Sempronia of Sallust Cat 25). This descendent of an aristocratic family had a way of changing her hair-styles and a tongue too sharp for censorious elders (Fasti 4. 305-312):17

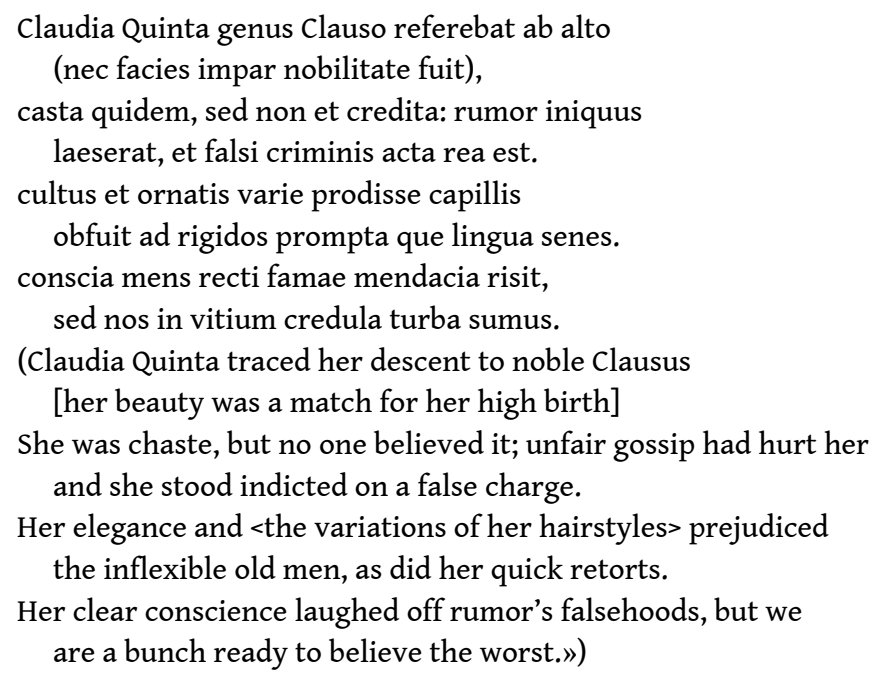

10 The import of line 310 is even questionable. Did Claudia's ready tongue answer back the elders directly, or did they simply disapprove of her quick wit, but the mention of rigidos senes as poles of social disapproval certainly recalls the reciprocal gaze mechanics of Catullus' rumores senium severiorum in Poem 5, while the Roman «crowd so credulous of rumors» embraces the populace with an inclusiveness that scarcely spares either Cicero or the jurors of Caelius Rufus' trial. Likewise reminiscent of Catullus is the smug interior sense of superiority that allows this target of scandal to laugh at famae mendacia. In this spirit Ovid's Claudia stakes all on a public test. While navigating the Tiber upstream beneath the eyes of a vast spectatorial crowd of young and old, commons and dignitaries, the ship of the goddess sticks fast in reeds and mud, refusing to move further. To the assembled spectators this mischance looks like a portent. With absolute command of ritual theatricality, Claudia Quinta steps forth from the contingent of matrons, scoops water from the river and imprecates the sky. She has not, of course, forgotten to unbind the controversial hair (Fasti 4. 313-318):

haec ubi castarum processit ab agmine matrum

et manibus puram fluminis hausit aquam, 
ter caput inrorat, ter tollit in aethera palmas

(quicumque aspiciunt, mente carere putant),

summisso que genu voltus in imagine divae

figit, et hos edit crine iacente sonos:

(When she advanced from the ranks of the chaste matrons

and scooped pure river water up in her hands,

she sprinkled her head three times, raised her hands three times

to heaven (the onlookers thought she was out of her senses),

So far no one understands her gesture, but with the by-standers regarding her as demented, she fixes her gaze upon the goddess and, dropping to one knee, utters a prayer in terms explicitly inviting divine vindication and public witness to her purity (Fasti 4. 319-326):

summisso que genu voltus in imagine divae figit, et hos edit crine iacente sonos:

'supplicis, alma, tuae, genetrix fecunda deorum, accipe sub certa condicione preces.

casta negor: si tu damnas, meruisse fatebor; morte luam poenas iudice victa Dea;

sed si crimen abest, tu nostrae pignora vitae re dabis, et castas casta sequere manus'.

(And on bended knees she fixed her gaze upon the image of the goddess, undid her hair and said:

'Fertile mother of the gods, kindly heed the prayers of your petitioner with this stipulation.

They say I'm not chaste: if you condemn me, I'll admit I deserved it; I'll pay with my life if convicted with a goddess as my judge.

But if the charge doesn't stick, give proof of my honorable life by action, and chastely follow my chaste hands.'

The rest is easy. Sounds of rejoicing acclaim her triumph. On the day following (343-345) she walks with joyous countenance ahead of the wagon carrying the deity who has verified her chastity. Temples and games now follow in due course. It is marvelous, says Ovid about his little drama, but the stage can bear witness (328). Wiseman plausibly takes this comment as evidence that the Republican repertoire must have included a fabula togata featuring Claudia Quinta. ${ }^{18}$ Consequently a reader may wonder whether Ovid's heroine learned her gestures from the stage, or whether the stage itself might have imitated her self-conscious ritual presence. If, as Gérard suggests, the theater was Livy's unnamed source, then Cicero surely did by-pass that tradition in constructing the ancient Claudia in complete moral opposition to Clodia Metelli. ${ }^{19}$

Subsequent writers perpetuate the story with variations. The Claudia mentioned in Propertius' Cornelia elegy 4.10.51-52, and thus in a version presumably prior to that of Livy, is already pulling the goddess' ship with a rope. ${ }^{20}$ Propertius' reference to her as a turritae rara ministra deae, sometimes interpreted to mean that she was a priestess of the goddess, might simply reflect the action which Livy calls her religiosum ministerium, or even be based upon a mistaken reading of the statue within the Palatine temple. Statius (Silvae 1.2.245-246) makes Claudia a virgo, ${ }^{21}$ but her specific Vestalization is a product of later sources that may well have confused her with two other Claudian woman of the Roman Republic. The more obvious of these (also mentioned by Cicero [pro Caelio 14.34] Livy [periochae 53] and Valerius Maximus [5.4.6]) is the Vestal Claudia who saved her father's triumph by interposing her sacrosanct person against obstructive action of a 
hostile tribune. ${ }^{22}$ A second possibility, however, is suggested by Ovid's mention in Fasti 5. 155-158 of the dedication of the Aventine temple to Bona Dea by a veteris Clausorum nominis heres, who, if not actually a Vestal, was at the time of the dedication a virgin (virgineo nullam corpore passa virum) and thus has been taken for a Vestal. ${ }^{23}$ All the same, the dedicated and publically responsible chastity of a Vestal is a different matter from that of a private individual and the point of vindication in Claudia Quinta's story is her status as a Roman matron, a person of private identity upholding her individual, and family, reputation by performing in the public sphere. In some post-classical accounts the pull by which Claudia leads Magna Mater's ship changes from the ship's own rope to a piece of the matron's personal clothing, either her girdle or her stola, both of course being symbols of chastity ${ }^{24}$. Gérard ascribes her sanctification to Claudian politics, enhancing its imperial standing through enhancement of its ancestors.

Still one may ask what claim on this celebrated family history this latter-day Claudia the dedicator might have had that would justify her choice of Magna Mater and Navis Salvia for her vow. Erika Simon proposes a Claudian date for the altar, resting her argument upon a likeness between its putative statue base and those on which the personified Etruscan cities stand at the base of the Emperor Claudius' throne in the Julio-Claudian ensemble of the theater at Caere displayed in the Vatican's Museo Gregoriano. Although Simon suggests that our Claudia might be a person claiming descent from Claudia Quinta, her name Syntyche seems more likely to make her more immediately a dependent of the imperial Claudian family, whose freedpersons came to number in legions. The style of the figures in the relief carving is very similar to that paradigm of freedpersons' art, the narrative panels of the Tomb of the Haterii. The use of statues in those reliefs also seem to me to present some productive analogies with the Claudia altar. On the tomb which emphasizes the attainment of an immortal afterlife the transformation of the deceased is signified by the form of a Venus statue, but the lower register shows also a statue of Hercules another guide to immortality. As iconographical symbols, however, these deities are shown in familiar postures; the resting Heracles being the famous image by Lysippus on the Capitoline, and the Venus finds parallels in the very popular custom of representing deceased women on the model of the Capitoline Venus. ${ }^{25}$ Whether the Claudia figure on the altar might also have an existing model is uncertain. In accordance with her notion that the dedicator was a familial descendent of Claudia Quinta, Simon takes the platform for a statue base and thus proposes a reference to the attested Palatine statue of the heroine (Figure 3). She furthermore explains the veil and loosely draped cloak as the suffibulum of a Vestal. ${ }^{26}$ Given, however, the date of 111 B.C. as a terminus ante quem for this indestructible statue, her being dressed as a Vestal seems most unlikely. Cicero, Livy and Ovid are all quite explicit about Claudia's status as a matron. Also the gesture of pulling the rope might be thought unusual in such a statue since chaste matrons are generally shown in the pudicitia pose, well-wrapped in their stolae. If indeed the figure does mean to represent a statue, and not simply a living person poised on a mole by the river bank, then its attitude would seem to have been influenced by literary information. On the other hand, the base may be thought to distance the present day Claudia, who is not a blood member of the Claudian gens' from pretentious identification with her legendary model while also asserting the continuity of the action that the story preserves.

Many scholars have taken this altar as evidence that the ship, under the name of Salvia, had acquired a cult of its own. ${ }^{27}$ and this would accord both with the place where the altar was stationed beside the river close to the initial disembarkation place of Magna 
Mater, and with the second Salviae of the inscription indicating that the actual vow has been directed to the ship itself. ${ }^{28}$ Salvia, one may note, is not a very common word in Latin, although in the repertoire of nomenclature it is the gens name of the Othones. Coarelli cites CIL 494 as evidence either for such an institution or else for the elevation of Claudia herself to cult status under the name of Navisalvia. ${ }^{29}$ Does this imply that by making the vow, Claudia Syntyche means to re-enact the role of the aristocratic savior of the city? In this case the situation she salvages would seem most likely to be a commercial one, which also will fit with the Aventine station of the altar.

Certainly Claudia's contribution in honor of Magna Mater must reflect her association with the Claudian family. CIL records three funerary inscriptions in the name of Claudia Syntyche, which might or might not refer to the same person. One (12015) is to a son named Ti. Antonius Syncleticus who died at the age of 16, another (15608) established by a Claudia herself in company with her husband «Paris» on behalf of the couple and their household familia and still another (15607) to a Claudia who lived 35 years by a husband named, Ti. Claudius Hermes. Should our Claudia be the wife of the Paris the actor, either the celebrated one, or any other by that name, this might explain the wealth that gave her an interest in shipping. Considering Paris' connection with the Claudian family, Gérard's suggestion that the legend of Claudia's miracle is a matter of Claudian family propaganda, might also help to explain the choice. ${ }^{30}$ Even the insignia of Attis that occupy the three minor faces of the altar might be taken to carry Claudian associations in the light of Turcan's information that the Emperor Claudius was the first of his family to elevate the goddess' companion to cult status and assign him a celebration. ${ }^{31}$ Even closer to an explanation, however, is the special patronage that the Emperor Claudius granted to ship owners in his campaign to support the grain trade based in his new harbor at Ostia (Suetonius Divi Claudii 19). The inclusion of privileges to women seems to indicate their consequence in the economy of the first century as owners of ships. ${ }^{32}$ So it seems that Cicero, while he launched Caelius Rufus' enemy Clodia upon a long-lasting career of infamy, at the same time contributed to the elevation of her Claudian ancestress to a no less notable plane of honor.

\section{APPENDIXES}

Figure 1 


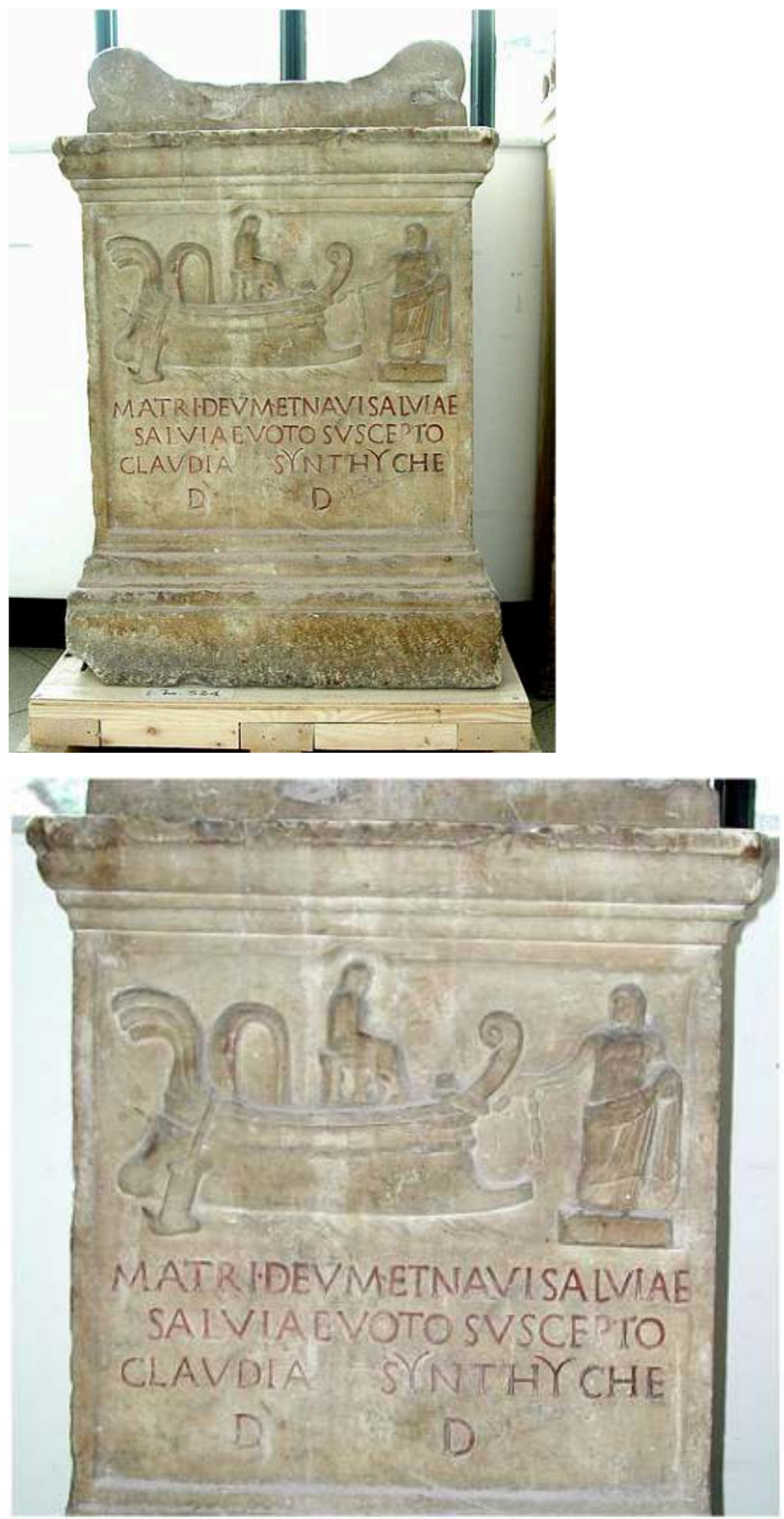

Figure 2 


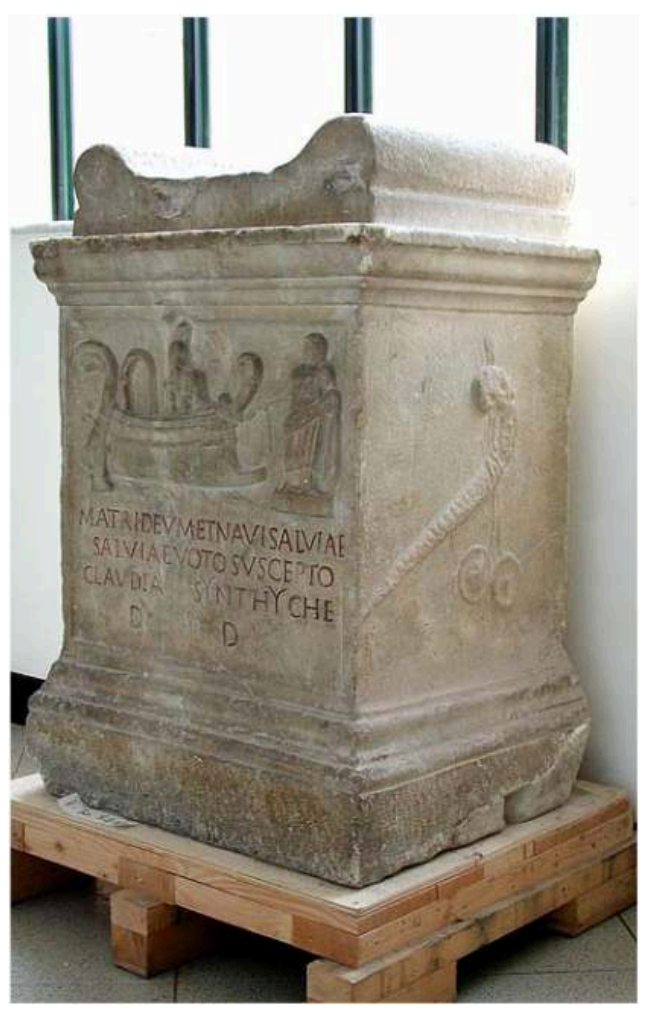

Figure 3

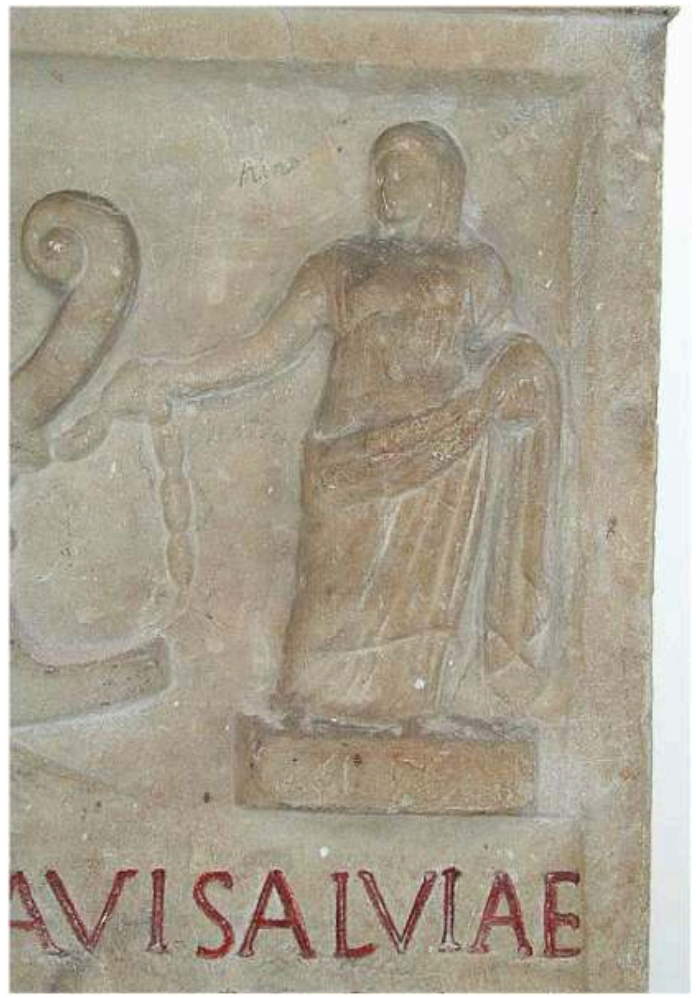




\section{NOTES}

1. Simon, Erika. «Altar der Göttermutter und ihres schiffes Salviae» in Helbig. Führer 24-25. 1175. M.J. Vermaseren. Corpus Cultus Cybelae Attidisque (CCCA) III. Italia-Latium. Leiden 1977. \#218. Pp. 45-46. At the time of these publications the altar was located in the Sala delle Columbe of the Capitoline Museum.

2. Vermaseren (above, note 1) 45-46.

3. Clearly the scene depicts the arrival of the goddess previously mentioned, although some of its features are unusual in this context. While representations of Cybele within the boat occur frequently, the goddess is usually wearing a mural crown and attended by her two lions, while the ship itself has both oars and sails. Several terra cotta antefixes from Ostia show the goddess in this form (Vermaseren [above note 8] \#s 429-435 and Pls. CCLXXII-CCLXXIV.)

4. CIL VI 493, a marble plaque now in the Museo Archaeologico ad Theatro Romano of Verona bears almost the same dedication and was also found on the Tiber bank. Vermaseren (above note 1) \#219. p. 46 and Pl. CXV.

$$
\begin{aligned}
& \text { navi. salviae et } \\
& \text { matri . deu d d } \\
& \text { claudia . sintyche ... }
\end{aligned}
$$

5. R.G.Austin, ed. M. Tulli Ciceronis: Pro M. Caelio Oratio. 3rd. Ed. Oxford. 1960, notes the relationship designated by progenies as uncertain. B. Dufallo, «Appius' Indignation: Gossip, Tradition and Performance in Republican Rome,» TAPA 131(2001)119-142. Remarks on the echoes of the Roman funeral oration conveyed by the word Imagines as well as the motif of conjuring the dead $a b$ inferis seldom exercised over so long a space of time.

6. P. MacKendrick. The Speeches of Cicero: Context, Law, Rhetoric London. 1995: 259-288. For interpretation of Cicero's characterization of Clodia as part of a strategy to model the speech on Roman comedy see K. Geffcken Comedy in the Pro Caelio with an Appendix on the Clodium et Curionem. Leiden.1973.

7. E.W.Leach «Gendering Clodius» Classical World 94(2001):335-359 discusses this oration.

8. E.S. Gruen. Studies in Greek Culture and Roman Policy. Leiden, 1990: 5-33, analyzes the cultural and political significance of the goddess' adoption as one of Rome's many receptions of foreign deities. He himself (17-18) favors the combination of the two latter arguing that Attalus took the stone from Mt. Ida to Pergamon in order to present it to the Roman ambassadors.

9. J. Gérard, «Légende et politique autour de la mère des dieux», REL 58(1980)153-175 comments on the variants in accordance with their sources.

10. Valerius Maximus. Facta et Dicta Memorabilia (1.8.11): <...quod Quintae Claudiae statua> in vestibulo templi Matris deum posita bis ea aede incendio consumpta, prius P. Nasica Scipione et L. Bestia item M. Servilio et L. Lamia consulibus, in sua basi flammis intacta stetit». The second fire was in A.D. 3.

11. Leen, Anne, «Claudia Oppugnatrix: the Domus Motif in Cicero's Pro Caelio», CJ 96(200-2001): 141-164.

12. J. Gérard (above note 9), 153-175.

13. Gérard (above note 9) 159 declares that Cicero's omission of the miracle story indicates his ignorance of it, but this seems highly unlikely, especially in view of the dramatic version.

14. The event was political from its origins. Gruen (above note 8 ) 27, explains the senatorial selection of young Nasica as vir optimus and of Claudia as the most outstanding matron "on the basis of purity and piety» as representing a political reconciliation, in which previously opposing parties came together in a display of national solidarity on the eve of Scipio Africanus' embarkation for Africa. Gérard (above note 9) 157 also saw the choices as a «balancing of families». 
15. Elaine Fantham, ed. Ovid; Fasti Book IV, Cambridge 1998, pp. 153-154. Additionally she observes that Scipio is, in Livy's account, the only male involved in the goddess' reception.

16. To the contrary R.J. Littlewood, who discusses Ovid's presentation of the entire festival, «Poetic Artistry and Dynastic Politics: Ovid at the Ludi Megalensis (Fasti 4. 179-372) CQ 31 (1981) 381-395, proposes that Ovid's objective in this friendly treatment is to curry favor with Livia by paying tribute to the virtues of an ancestress that might be taken to resemble her own matronly profile.

17. This and the following translations from the Fasti are taken from B.R. Nagle Roman Holidays. Bloomington, Indiana. 1996, 113-114.

18. Wiseman, T.P. «Satyrs in Rome?» in Historiography and Imagination: Eight Essays on Roman Culture. Exeter, 1994.68-85. Although Littlewood (above note 16) 394, simply dismissed Ovid's remark as «naive», Wiseman rightly values it as evidence both for Ovid's use of drama, and for the importance of the theater as a medium for the transmission of Roman stories. Although he also characterizes it as a "genuine miracle story» turning on the direct intervention of gods, he allows that we have no idea of the form which it took. In fact M.R Salzman, «Cicero, the Megalenses, and the Defense of Caelius,» AJP 103(1982):299-304, went beyond this opinion in conjecturing that the drama of Claudia formed one traditional feature of the Megalensia celebration, which was, of course, in progress at the very moment of Cicero's speech. Dufallo (above note 5) builds upon this suggestion to explore the performative aspects of drama within oratorical performance, and also notes how Cicero uses the authority of ritual to separate two kinds of slanderous gossip, corroborating that about Clodia's unmatronly conduct while diminishing talk about Caelius to insignificant patter.

19. Gérard (above note 9) while noting, 161-162, that Livy would not characteristically have passed over a detail on the simple grounds that it was unbelievable, all the same proposes that he would have considered theatrical production a source unworthy of mention in historical narrative.

20. Propertius. 4. 10. 51-52.

vel tu, quae tardam movisti fune Cybeben,

aclaudia, turritae rara ministra deae.

Littlewood (above note 16) 385 n. 25, adds that Cornelia's widowed husband, Aemilius Lepidus, subsequently made a Claudian marriage.

21. Statius, Silvae 1.2. 245-246:

Non Claudia talis

respexit populos mota iam virgo carina.

22. Littlewood (above note 16) 383, cites the second destructive fire of A.D. 3 and Augustus' rebuilding of the temple at the very time that he was forced to adopt Tiberius Claudius as his heir. «Livia Triumphed».

23. H.H.J. Brouwer "The Great Mother and the God Goddess: The History of an Identification», in M.B. de Boer and T.A Edridge, ed. Homages à Maarten J. Vermaseren, Vol. I (Leipzig, 1978). 142-159 discusses two points of confusion here. The first is between this otherwise unattested heres Clausiorum and the well-known Claudia Quinta, an effect that he attributes to Ovidian imprecision. Second is the conflation of the two goddesses, both with maternal associations, but differing in their ethnic genesis and in the nature of their cult worship. All the same, his account of the «first undoubtedly authentic Bona Dea statuette» as «a woman seated on a throne clad in chiton and mantle» might by taken to explain, also by confusion, the unusual costume of the goddess on the altar.

24. Although it is difficult to ascertain what was the composition and nature of the pull shown on the altar, which has more than once been compared with a string of sausage links, it would seem to be neither of these, but presumably it was either a boat chain or an infula. 
25. D’Ambra, Eve. «The Calculus of Venus: Nude Portraits of Roman Matrons», in N. Kampen, ed. Sexuality in Ancient Art. Cambridge. 1996: 219-232.

26. Simon (above note 1) 1175.

27. The first Salvia of the inscription, apparently in apposition with the dative navi, must be the name of the ship receiving the dedication jointly with the goddess, while the second has been taken for the carver's error. This to my mind is hard to credit in view of the good cutting of the letters and the careful spacing of the words. I would prefer to accept this Salviae as a second dative with the ablative absolute voto suscepto. F. Coarelli, «I monumenti dei Culti Orientali in Roma, in U. Bianchi and M.J. Vermaseren ed. La soterioloogia dei culti orientali a Roma. Leiden (1982) 42-46. P. 43 also finds the notion of such a cutting error unsatisfactory.

28. These include M. Beard, J. North, S. Price. Religions of Rome: Volume II, A Sourcebook. Cambridge. 1998: 43-47 and Coarelli (above note 27) 42-46.

29. CIL VI 494: matri . deum et . navi . salviae/ q. nunnius/telephus . mag/col . culto . eius/D $v S v D v D$.

30. J. Gérard (above not 9), 153-175.

31. R. Turcan, The Cults of the Roman Empire, A. Nevill trans. From Les cultes orientaux dans le monde romain, (Les Belles Lettres 1989;1992) Oxford/Malden Mass. 1996. 43-44.

32. I owe this refernce to Marilyn Skinner.

\section{ABSTRACTS}

Among the items of sculpture from the Capitoline collection now housed in the Museum of the Power Station Montemartini is a marble relief altar of the Claudian Period (E. Simon's dating) dedicated to the mater deorum and the navis salvia and depicting the arrival of the goddess Cybele at Rome by ship. The dedicator is one Claudia Syntyche and the sculpture alludes to the legends attached to a much honored woman of the Claudian family whom Cicero, in his oration pro Caelio brought on stage in a cameo appearance to bolster his case against the controversial contemporary woman Clodia Metelli as one of the accusers of his client M. Caelius Rufus. This paper will consider questions raised by the iconography of the altar with reference to the development of Claudia's legend in Roman mythology and subsequently ask who was this Claudia the dedicator and why did she choose Magna Mater for her vow?

\section{INDEX}

Mots-clés: Claudia Quinta, Claudia Syntyche Altar, Relief Magna Mater, dedicatory inscription, Cicero's Pro Caelio, Ovid, Fasti IV

\section{AUTHOR}

\section{ELEANOR WINSOR LEACH}

University of Indiana

leach@indiana.edu 